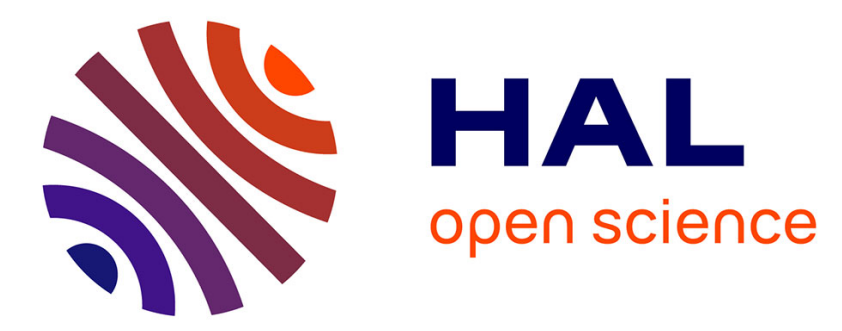

\title{
Building cities on financial assets: The financialisation of property markets and its implications for city governments in the Paris city-region
}

\author{
Antoine Guironnet, Katia Attuyer, Ludovic Halbert
}

\section{To cite this version:}

Antoine Guironnet, Katia Attuyer, Ludovic Halbert. Building cities on financial assets: The financialisation of property markets and its implications for city governments in the Paris city-region. Urban Studies, 2016, 53 (7), pp.1442-1464. 10.1177/0042098015576474 . halshs-01289407

\section{HAL Id: halshs-01289407 \\ https://shs.hal.science/halshs-01289407}

Submitted on 2 Apr 2020

HAL is a multi-disciplinary open access archive for the deposit and dissemination of scientific research documents, whether they are published or not. The documents may come from teaching and research institutions in France or abroad, or from public or private research centers.
L'archive ouverte pluridisciplinaire HAL, est destinée au dépôt et à la diffusion de documents scientifiques de niveau recherche, publiés ou non, émanant des établissements d'enseignement et de recherche français ou étrangers, des laboratoires publics ou privés. 
Title: Building Cities on Financial Assets: The Financialization of Property Markets and its Implications for City Governments in the Paris City-Region

Authors:

Antoine Guironnet, LATTS, Université Paris-Est, France

Katia Attuyer, University of York, UK

Ludovic Halbert, LATTS, Université Paris-Est, France

Abstract: The 2008 global financial meltdown redirected attention to the entwinement of financial markets and the urban built environment. Against that background, recent works in urban political economy have focused on how city governments support the rent-maximization strategies of landowners, thereby reinforcing "the increasing tendency to treat land as a financial asset" (Harvey 1982). However, this perspective paradoxically understates the importance of market finance actors, neglecting to demonstrate how, in practice, such financial investors, who have been shown to adopt selective investment practices, shape urban redevelopment projects. In this article, the role of financial investors is analyzed through a case-study of a large-scale urban redevelopment project on the outskirts of the Paris city-region (city of Saint-Ouen). The analysis of negotiations over urban design and economic development issues - raised by property developers seeking to fashion commercial properties as investment assets - reveals the unevenness of a local authority's ability to implement an agenda that potentially diverges from the expectations of financial investors. Accordingly, given the growing importance of investors in the ownership of the built environment, the article considers urban redevelopment as the outcome of power relations that originate in the circulation of investors' expectations. These expectations are met through translating market finance categories (risk, return, and liquidity) into elements of the urban fabric. This bears substantial consequences for policy-making, given the current context of austerity, as municipal authorities are increasingly constrained to rely on property markets, Urban redevelopment projects are thereby increasingly shaped to provide investment assets for financial investors. 
Keywords: city governments, financialization, financial investors, property developers, urban development projects, Paris city-region, Saint-Ouen, France

Funding: This research was supported by the Urban and Architecture Plan (Plan Urbanisme, Construction, Architecture) of the French Ministry for Public Works (MAPA 1500940 217) and from the Sustainable Development Research Network for the Île-de-France Region (R2DS 2010-09).

Aknowledgements: Earlier versions of this work have been presented at the RC21 "Resourceful Cities" conference (Berlin, August 2013) and the "Real Estate / Financial Complex" seminar (Leuven, December 2013). We wish to thank the three anonymous referees for their insightful comments, as well as Jasper Cooper for his help in copy-editing. The usual disclaimers apply.

\section{Introduction}

From infrastructure to real estate, multiple portions of the urban built environment have morphed into financial assets (Leyshon \& Thrift, 2007; Torrance, 2008; Aalbers, 2012; Guironnet \& Halbert, 2014). While States are admittedly involved in this intertwining of financial markets and the built environment (Gotham, 2006), more research on the "recent processes of financialization from the perspective of city governments" (Weber, 2010, p. 256) is required. This paper endorses this call and examines the ability of city governments to implement redevelopment projects, when the property markets on which they rely to transform the urban fabric are increasingly morphing into bundles of assets in financial portfolios.

In the aftermath of the Global Financial Crisis (GFC), research into propertyled urban redevelopment projects has explicitly sought to take "financialization" into account. Building on Harvey's concept of "land as a financial asset" (2006 [1982], p. 347), and highlighting how city governments are incentivized to treat 
land "on strictly financial grounds" (Christophers, 2010, p. 98), the uneven spatial, social, and political outcomes of redevelopment projects have been viewed as reflecting a process of financialization understood in terms of pure rentmaximization by landowners. However, in adopting a conception of financialization as a general process affecting all landowners irrespective of their characteristics, this approach paradoxically fails to fully engage with the growing importance of financial markets and investors, and with their impact on the redevelopment of the urban built environment.

This paper seeks to fill this gap by foregrounding the financial investors who acquire and manage real estate assets on behalf of institutional clients and households (Attuyer et al., 2012b). As already observed, these intermediary investors provide a crucial link between financial markets and commercial real estate (Ball, 1986; Environment \& Planning A 26(2 \& 5), 1994; Halbert et al., 2014a). Drawing on categories and risk-adjusted return calculation techniques derived from market finance (Crosby and Henneberry, 2016; Henneberry \& Roberts, 2008; David \& Halbert, 2013), their portfolio management practices favor socially processed investment criteria that are highly selective in terms of preferred investment locations, types of buildings, or tenant profiles (e.g. Guy et al., 2002; Halbert et al. 2014b; Henneberry \& Mouzakis, 2014). Recent studies underscore the key role of property developers in mediating such investor expectations, although the process is not without potential tensions (David \& Halbert, 2014; Searle, 2014; Theurillat \& Crevoisier, 2014). In other words, property developers contribute to the circulation of their clients' selective investment criteria to other key actors involved in urban redevelopment.

This paper seeks to analyze how city governments can redevelop their localities in conditions where property developers increasingly, if not predominantly, promote the prerequisites of the financial investors for whom they assemble buildings. The underlying hypothesis is that a key aspect of the financialization of the urban built environment is the growing role of financial investors in shaping contemporary Urban Development Projects - via real estate markets - and that this trend leads to the construction and occupancy of urban space that increasingly corresponds to their expectations. 
We posit that these expectations, their circulation, and any ensuing tensions will be most apparent in cases where the agendas of city governments are at odds (to varying degrees) with the expectations of the investment industry. This implies shifting the focus away from configurations where city governments pursue entrepreneurial strategies that officially aim to stimulate property investment (Healey et al., 1992). Therefore, this paper questions the room for maneuver of a city government whose development goals potentially diverge from the expectations of financial investors. It analyzes the issues raised, the instruments of negotiation, and the potential outcomes when a local authority engages with a financializing property industry.

The paper is organized into six sections. After illustrating how the financialization of urban redevelopment has been analyzed in terms of a rentmaximization principle applied indiscriminately to private developers and city governments, the first section offers an alternative perspective. It suggests shifting the focus to the potentially conflictual circulation of the expectations of the financial intermediaries who invest in the ownership of the built environment. The second section introduces the research objective and its focus on city governments' ability to steer redevelopment projects in a context of financialized property markets, as well as explaining the rationale for the case-study approach and the case selected. Section 3 explains how the municipality of Saint-Ouen, a former industrial suburb adjacent to Paris which has witnessed property investors "knocking at the door" (Mayor's public speech, 01/12/2013) since the 2000s, nonetheless avowedly seeks to preserve access to land for lower-income groups and lower value-added activities. As an illustration of this strategy, section 4 presents the "Docks", the municipality's 100 ha urban redevelopment project. In sections $5-6$, the paper analyzes the negotiations between the municipality and the property development holding company that acquired a large tract of land in the Docks thanks to the provision of office buildings for financial investors. The conclusion discusses the empirical and theoretical findings, as well as policy and academic implications. 


\section{City governments, urban redevelopment, and the financialization of property markets}

Academic interest in local authorities and property investment has been particularly strong with regard to property-led urban regeneration policy, especially since its implementation by the Conservative government in the UK in the 1980 s (Healey et al., 1992) as well as in the USA (Wolf-Powers, 2005). According to this policy rationale, the local public sector should attract the private investment necessary for the provision of new property, which will in turn support economic development (Healey et al., 1992, p. 277). The pros and cons of this supplyoriented policy agenda have been amply discussed (Turok, 1992). Less attention has been paid, however, to the fact that property-led redevelopment projects may contribute to the intermingling of the financial and the property industries, be it in global cities (Pryke, 1994; Fainstein, 2001) or more peripheral areas (Healey, 1994).

Most critical studies have instead interpreted this supply-oriented policy in terms of the shift in urban governance from managerialism to entrepreneurialism (Harvey, 1989). As such, it is seen as related to the wider process of neoliberalization (Taşan-Kok, 2010, 2012) through which the regulatory framework, including local institutions and policies, is re-engineered according to a market-inspired ideology (but see Le Galès, 2012). This theoretical framework developed in particular around the study of large-scale Urban Development Projects (UDPs), which have proliferated in metropolises (Halbert, 2007) to the extent that their existence has become a 'given', unquestioned by academics (Orueta \& Fainstein, 2008, p. 765). In their survey of several UDPs in Europe, Moulaert et al. (2003) depicted these property-led regeneration schemes as the very embodiment of planning policies infused with neoliberal ideas. According to these critics, urban redevelopment is thus driven by private sector rent-capture strategies permitted, if not encouraged, by supportive planning policies and public investment (Moulaert et al., 2003, pp. 259-60; see also Swyngedouw, 2005, pp. 67-8). As a result, instead of stimulating equitable economic development through 
the expected trickle-down of wealth, UDPs are seen as resulting primarily in sociospatial polarization (but see Raco \& Henderson, 2009) at the expense of democratic accountability.

Following the 2008 GFC, a handful of works in urban political economy have shed light on the "financialization of urban redevelopment" (Rutland, 2010). Such works share a similar critical standpoint with previous work on the neoliberalization of urban redevelopment, especially with respect to the observed outcomes. Yet, drawing mostly on Harvey's theoretical argument of "land as a financial asset" (2006 [1982]), their analysis focuses more narrowly on the circumstances and mechanisms under which property-led UDPs are the sites where land is increasingly treated as a financial asset, including by city governments.

Weber's seminal work on Tax Increment Financing (TIF) districts in Chicago explores how a city government may operate as an "active agent of financial liberalization and integration" (2010, p. 257), by observing how it devised a sophisticated financial instrument to finance the costs of urban redevelopment. Under the TIF scheme, securities are issued for financial investors, underpinned by the promise of future fiscal income streams generated from the regeneration plan itself. To design financially attractive municipal bonds, the city government targets areas that offer inter alia rent-gap potential, i.e. areas where large projects offer the potential for "[tax] revenue-generating use(s)" such as retail and private housing (versus social housing and green spaces) (ibid., pp. 265-269). Although Weber does not claim to draw primarily on Harvey's argument, her work nonetheless illustrates how city governments adopt the "increasing tendency to treat land as a financial asset", as already suggested by Haila (1988, p. 92).

Shifting the focus to strategic planning, Kaika and Ruggiero (2016) emphasize the enabling role played by the municipality of Milan in the treatment of the Biccoca estate by its owner - the tire firm Pirelli - as a pure financial asset. Although it was the company that initiated the shift in accounting practices, which involved switching the basis of its valuation of industrial land from "an investment that depreciates over time" to "the rent it would potentially yield in the real estate market" (ibid., p. 6), the Milanese authorities were nonetheless needed: not only to 
promote Pirelli's Biccoca project to initially reluctant local trade unions, but also to provide the planning changes and approvals that were central to unlocking redevelopment, i.e. "to maximize potential rent production" (ibid., p. 13).

In the case of the 22@ UDP in Poblenou, Charnock et al. (2014) argue that Barcelona municipality did more than just play an enabling role for developers with "profit-maximizing rentier practices" (p. 208). Because of its use of the value capture financing (VCF) scheme, the city government adopted the treatment of "land as a financial asset" in order to limit its investment and recourse to debt (ibid., p. 204). The funding of public goods (green spaces, social housing, and infrastructure) was achieved by the 'capture' - in kind or in hard cash - of between $10 \%$ and $30 \%$ of the value of planned developments. Like private developers and investors, the city government consequently adopted the same maximizing attitude to land-based rents. For Charnock et al., this led to a drastic limitation in the municipality's original aim of enhancing the Knowledge Based Economy (KBE) sector through the 22@UDP: the VCF scheme actually facilitated the eviction of some KBE firms, ${ }^{1}$ because it contributed to a surge in land prices.

In these different case-studies, city governments either treat land as a financial asset or enable private developers to do so. These converging findings build on Harvey's concept of "land as a financial asset" developed in his analysis of land in the context of capitalistic accumulation $\left(2006\right.$ [1982]). ${ }^{2}$ Here, land is treated by property owners as "a form of fictitious capital" or "interest-bearing capital", and landownership achieves its "true capitalistic form" whenever property owners consider their land in terms of "the rent it might yield". There is thus "a central guiding feature in the behavior of all economic agents, regardless of exactly who they are and what their immediate interests dictate" (ibid., p. 347). This reflects a universal principle of land value maximization pursued by landowners and allied interests (see also pp. 368-9). Although Harvey's argument was developed before the widespread use of the notion, it has nonetheless been subsequently employed precisely to highlight financialization as the "pivotal and unifying concept (...) of 'things' increasingly being valued on strictly financial grounds" (Christophers, 2010, p. 98; see also Moreno, 2014, p. 256). Accordingly, it constitutes the 
theoretical basis for most recent critical works on property-led urban redevelopment projects involving local authorities and financialization.

However, our aim here is to cast a different light on these "financial grounds" and their relevance. First, by considering the increasing and distinctive role of financial investors in the built environment through the continuing incorporation of properties (and infrastructures) into their asset portfolios. Second, as observed in other fields such as cultural economics (Erturk, et al., 2008) or social studies of finance (Knorr-Cetina \& Preda, 2005), these "financial grounds" not only call attention to a particular sector (the financial industry), but also to a specific set of rationales, techniques, and practices rooted in market finance. In sum, "financial grounds" designate a set of investment intermediaries as well as their social activity. So, instead of considering financialization as a universal principle of land value maximization - which might lead to a blurring of the potentially distinctive and active role of financial actors - this paper contends that the ability of city governments to steer urban redevelopment projects can be understood by probing their more or less direct interactions with financial intermediaries who manage property portfolios.

The "meteoric rise of property as a sphere of investment" (Ball, 1986, p. 459) has been documented since the 1980s in the UK/U.S. contexts, where institutional investors are described as "office-rent receivers" (ibid., p. 455; Healey, 1994; Pryke, 1994; on the U.S. see Feagin, 1987), to the extent that buildings have been described as becoming "quasi-financial assets" (Coakley, 1994). Recent research (see Halbert et al. (2014a), for an overview) has acknowledged the role of 'financial investors' in the financing, ownership, and management of the built environment, and especially of commercial real estate (Attuyer et al., 2012b). With the globalization of property markets and the simultaneous dissemination of financial techniques and practices beyond UK/U.S. borders, the financialization of the business strategies, rationales, and practices of property investment companies has been systematically observed (Crosby \& Henneberry, 2016;Henneberry \& Roberts, 2008; Lizieri, 2009; Nappi-Choulet, 2009; Halbert, 2013). In particular, starting with an analysis of how real estate assets are managed using modern portfolio management theory and practices, the academic literature demonstrates 
how risk-adjusted returns are not an abstract economic principle inherent to capitalistic accumulation but the output of a social process whereby financial investors in real estate translate categories of market finance into the built environment (see David \& Halbert, 2014, for a case-study on the Mexico cityregion, as well as David, 2014). ${ }^{3}$ This social process of translation is achieved through quantification and classification, which allow commensuration between different investment opportunities (see Espeland \& Stevens, 1998). It is further influenced by the economic modus operandi adopted by these financial organizations-which, for example, may seek to manage fewer but larger assets to generate economies of scale. This results in investment strategies that rely on numerous selective criteria. Recent studies of the investment patterns of financial investors reveal strict criteria for the location of investments (Lizieri, 2009; Henneberry \& Mouzakis, 2014; Stevenson et al., 2014; Halbert et al., 2014a), for the characteristics of property assets (e.g. building size and type, integration with the surrounding urban fabric), and for the types and numbers of tenants per building (Attuyer et al., 2012a; Halbert et al., 2014b). However, there remains a dearth of studies on how such expectations affect urban redevelopment projects. More precisely, it remains to be seen how public authorities support, negotiate, or even challenge investor selectivities through interaction with the property development industry, whose business model is mostly based on delivering the type of buildings and leases expected by financial investors (Theurillat \& Crevoisier, 2014; Guironnet \& Halbert, 2014).

Endorsing Weber's call for research into the "recent processes of financialization from the perspective of city governments" (ibid., p. 256, our italics), the present article thus analyses the ability of city governments to implement an urban redevelopment project in increasingly financialized property markets. Acknowledging the potentially "important role played by city governments in shaping and being shaped by financial markets" (ibid.), the paper draws on a case-study to analyze planning issues and tools of concern to city governments involved with the developers who work for financial investors. It also casts light on the spatial and socio-economic outcomes of a UDP, arising from 
tensions between municipal authorities and financial investors over what a redevelopment project needs to be.

\section{Research methodology}

To investigate how a city government may attempt to implement its project in the light of the financialization of the property market, the investigation adopted a case-study approach suited to exploratory research. Bearing in mind the limits to generalization that case-study research allows, such a methodology supports the purpose of the inquiry by enhancing our understanding of an under-researched subject, namely the circulation of the expectations of financial actors in urban redevelopment projects. The case-study entailed a survey of the city government's policy agenda, with a specific focus on urban, social, and economic development issues, as well as on understanding the redevelopment project (in terms of its main goals, governance, and funding) and its evolution. The aim was to track over time the negotiations between the city government and the property developers involved in the UDP. In the approach to the research, there was no preconceived idea of what negotiation topics should be analyzed. Instead, we took into consideration issues that gradually emerged over the course of the research project, with a particular focus on any relating to property acquired by financial investors. This consisted mostly of commercial real estate, both existing (e.g. Valad storage park, 72,000 sq.m.) and new (offices).

This research used multiple qualitative data collection methods, including semi-structured interviews, field observation, and reviews of a range of published and unpublished documents produced by the municipality and the property industry. These included a comprehensive set of planning documents (e.g. local zoning plans, UDP masterplan), official municipal land redevelopment records (e.g. financing scheme, concession contract, agreements, minutes of municipal council meetings) and documentation from the real estate development industry (e.g. official agreements, brochures). This research was rounded out by an analysis of press articles. 
Although secondary sources provided insight into the characteristics of the project, there was a shortage of key data needed for a full understanding of how the project came into existence and evolved to suit different demands, and what the critical issues of negotiations were, particularly concerning the provision of commercial properties acquired by financial investors. For this reason, semistructured interviews were conducted to acquire the additional information necessary to achieve the research aims. A total of 20 semi-structured interviews were held between May 2012 and September 2013 with actors directly involved in the redevelopment initiative, including: elected officials, civil servants from municipal planning and economic development departments, city-appointed planners and development corporation staff, private developers, financial investors, and consultants. The targeted interviewees were individuals identified in official documents as participating in the project and those likely to be involved because of their position within their organization. Further participants were recruited through a "snowball" technique, which provided access to people belonging either to the same organization or to an individual's professional network. The questions raised during the interviews concerned both the city government's agenda and the negotiations relating to properties owned by or developed for financial investors. The discussions covered a wide array of issues, from the reasons for the interviewees' involvement in the project to the difficulties encountered during its implementation.

The data from the different interviews and documents were analyzed for the purpose of systematic comparison. This triangulation process aimed to identify the multiple positions and interests and to track how they changed over time, as well as to compare the goals pursued and the final outcomes.

The selection of the case was based on two main criteria. Firstly, the UDP had to be in a locality that was attractive to financial investors. Secondly, the research objective required a city government that was not actively pursuing an entrepreneurial strategy intended to accomodate property investment. In other words, the priority was to find a local authority sufficiently determined to limit hikes in land prices and with aspirations for urban redevelopment that were at least 
partially divergent from the expectations of financial investors as observed in the existing academic literature.

\section{Redeveloping the Red Belt when financial investors "knock at the door"}

As an overview of its historical developments and current policies indicates, Saint-Ouen manifests both of these prerequisites. Indeed, as a long-established Red Belt municipality, it is distinguished by its support for redistributive policies that seek to share the benefits of brownfield redevelopment on former industrial land amongst its constituents.

The municipality is part of the Red Belt, a series of towns in the periphery of Paris, which started to coalesce into a distinctive entity in the 1920s through the control of local leadership by the French Communist Party (Fourcaut 1995). ${ }^{4}$ The Red Belt's substantial development is rooted in the nineteenth century center/periphery Fordist pattern under which manufacturing activities and bluecollar jobs were concentrated in municipalities adjacent to Paris. Against this background, there emerged a distinctive municipal agenda of redistribution: 'municipal communism' emphasizing investment in social housing, public infrastructure, and community programs, especially for blue-collar constituencies (Fourcaut, 1995; Pouvreau, 2009; Bellanger, 2013).

Since the 1960s, the Red Belt has had to contend with deindustrialization. To preserve its identity and support blue-collar households, planning was employed as a defensive strategy in many municipalities (Fourcaut, 1995, p. 81; Albecker, 2009). In the 1970s-80s, for instance, the Saint-Ouen municipality deliberately maintained a pattern of industrial land-use and limited the construction of private housing through zoning, in the hope of preserving the existing urban fabric (see Fourny, 1986 on the "factory within city" model). This did not prevent the population falling from 52,000 to 39,700 between 1962 and 1999 (Ville de SaintOuen, 2008, chap. 2).

$<<$ Insert Figure 1 here $>>$ 
In the 1990s, Saint-Ouen became more attractive to business services. Located halfway between the western business center of La Défense and the emerging Plaine Saint-Denis and alongside the Parisian Périphérique ring road (see Figure 1), abandoned manufacturing sites offered substantial land availability. As in other such "pericentral" locations (Halbert 2008), Saint-Ouen was in a situation to accommodate evolving corporate locational patterns. Seeking enhanced operational synergies and lower location costs, companies have been attempting to combine teams scattered across the Paris conurbation within large-scale buildings in pericentral locations. This went hand-in-hand with concomitant changes in the ownership of commercial properties in the mid-1990s. Divesting 'non-core activities' to satisfy their shareholders, corporations began outsourcing their real estate, noticeably through sale-and-leaseback arrangements with investors (NappiChoulet, 2002; Halbert, 2013). The arrival of Anglo-Saxon investors and the wide dissemination of their market finance-based techniques became a further catalyst for the fledgling financialization of French commercial property markets, which had started to emerge in the 1970s (Marty, 2004; Nappi-Choulet, 2009; Halbert et al., 2014b). The consequences for several municipalities in the northern Red Belt were spectacular. Capitalizing on public investment in infrastructure, 'opportunistic" Anglo-Saxon investors developed properties that were then resold to more risk-averse institutional investors once long-term leases had been arranged (Nappi-Choulet, 2006). With financial investors literally "knocking at the door" according to our calculations, $85 \%$ of the newly-built 226,500 sq.m. Victor Hugo business area (see Figure 2) is currently owned by such property investors - Saint Ouen's commercial property stock has multiplied fourfold since the 1990s (Ville de Saint-Ouen, 2008, chap. 2, p. 92). Although it is currently affected by the glut in commercial office space in the Paris city-region, it is considered as an 'emerging market' by the real estate brokerage industry. The Grand Paris Express transitoriented development (TOD) project and the two new subway stations associated with it should further improve the locality's prospects, together with the recent recognition of Saint-Ouen as part of the creative industries cluster created jointly with central government. 
Given this renewed interest in their territory, elected officials in the Red Belt face a stark dilemma (Albecker, 2009). To facilitate socio-spatial cohesion and sustainability, elected officials in Saint-Ouen have repeatedly stated their intention to preserve the diversity of the economic fabric by carefully monitoring the development of office premises. This commitment is enshrined in strategic planning documents (Ville de Saint-Ouen, 2004, 2008). However, the sale of office building rights is increasingly important as a way of covering the cost of decontaminating brownfield sites and providing housing and public amenities for their low-income constituents. Yet, at the same time, office developments help to fuel mounting land pressure and may therefore lead to the displacement of low income groups and activites that Saint-Ouen's elected officials want to preserve.

This dilemma echoes wider shifts in French planning policies and financing. From the 1950 s to the 1970 s, development projects were mostly based around the provision of social housing and thus largely orchestrated, financed, and guaranteed by the central state apparatus. Since the 1980-90s, many developments have been centered around business property (Janvier, 1996, p. 30). Moreover, following successive devolution measures (1982 and 2004), the central planning apparatus has been superseded: local authorities and their arm's length Development Corporations (DCs) have increasingly assumed effective control for steering urban redevelopment projects (Caillosse et al., 1997; Menez, 2008).

In this context of increased strategic autonomy but reduced financial support from the State and greater dependence on commercial real estate developments, Saint-Ouen's current Mayor - in office for the past 15 years at the time of writing has developed an agenda explicitly designed to combat the eviction of low-income households and lower added-value firms, while providing access to public services. As traditionally found in Red Belt municipalities, planning has been integral to this agenda in two ways: proactive intervention to provide housing and a redistribution strategy based on taxing business development (i.e. both property developers and occupying local firms).

With regard to the first aspect, the share of social housing has remained high ( $40 \%$ of the housing stock, twice the national legal requirement), while private 
housing has been subject to stringent regulations. For instance, before constructing new market-rate housing units, property developers must first ratify a charter that stipulates a preferred size and type of unit, a cap on selling prices, and a maximum proportion of units for the buy-to-let market. Furthermore, shortly after the property boom, as in other pericentral cities, an agreement was signed in 2002 between the State and the municipality making the construction of additional construction subject to the provision of new housing. This was part of a regional policy under the Regional Master Plan aimed at improving the balance between the number of jobs and inhabitants (Préfecture de la Région d'Île-de-France \& Direction régionale de l'équipement, 1994, p. 36).

As regards redistribution, the early 2000s business property boom around some of Saint-Ouen's main transit nodes (see Figure 2) enabled the municipality to pursue wealth redistribution through local taxes. This kept the municipal budget afloat through tax contributions from newly established businesses (business and property taxes). It also led to the construction of infrastructure and public space, notably by means of taxation levied on property developments through the establishment of two dedicated planning zones (zones d'aménagement concertée, ZAC) which, under national planning regulations, enable the municipality to obtain financial contributions from all developers to support the cost of local public amenities (participation au financement des équipements publics).

All in all, Saint-Ouen is an example of a locality where financial investors are "knocking at the door" while the city government pursues a strategy of sociospatial cohesion and redistribution that includes robust negotiations with property developers whenever necessary.

\section{Planning the post-industrial Red Belt: the Docks redevelopment project}

Within this context, the Docks de Saint-Ouen UDP has officially been used to showcase the municipal policy agenda. Immediately following its original formulation in 2004, elected officials and the municipal administration have reiterated the need for the project to be consonant with the existing urban, 
economic, and social fabric of the city (Interviews 002, city-appointed architectplanner; 010, Economic development municipal administration; 014, Economic development consultant). Located in the northwest of Saint-Ouen (see Figure 1), the site covers over 100 ha of land, $25 \%$ of municipal territory. Historically an area dedicated to industry, industrial decline has left vacant plots that coexist with still extant 'bulky' activities (waste and energy utilities, storage parks, etc.)

In 2004, the publicly-listed French property holding company Nexity bought 18 ha of land in the zone. At the same time, the removal of the security perimeter following the closure of hazardous industries in the vicinity officially opened up new planning possibilities (Interview 002, city-appointed architect-planner). To conduct pre-operational studies, the municipality appointed a planning architect as well as Sequano, the Development Corporation (DC) for the Seine-Saint-Denis district (département). ${ }^{6}$ As is common practice for most large-scale redevelopment projects in France, a special planning zone (ZAC) was set up in 2007 (and adjusted in 2010), and in 2008 the necessary adjustments were made to the municipal zoning regulations to convert the land-use status from non-residential to mixed-use. The municipality subsequently chose to appoint Sequano to conduct the redevelopment on an arms' length basis via a concession arrangement.

In order to build "a new area of great urban and environmental quality, exemplary in the diversity of its urban and social fabric, its built density showcasing its industrial heritage" (Ville de Saint-Ouen \& Sequano Aménagement, 2010, p. 1), three objectives were emphasized: mixed land-use, a new supply of commercial buildings to increase economic diversity, and street-level amenities (e.g. retail) for a vibrant neighborhood community. The total planned construction program covers 824,000 sq.m. (see Figure 2), with social housing accounting for $40 \%$ of all residential development. The initial estimated cost was $€ 500$ million (later revised to $€ 657$ millions, Sequano Aménagement, 2014), of which $€ 242$ million alone was dedicated to public space and infrastructure (Ville de Saint-Ouen \& Sequano Aménagement, 2010). More than a quarter of the investment ( $€ 132$ million) comes from subsidies granted by Saint-Ouen. This substantial commitment has repeatedly drawn the attention of the State's regional jurisdiction responsible for monitoring local public finance, which had sounded the alarm over 
Saint-Ouen's increasing financial difficulties prior to the development plan (Chambre régionale des comptes d'Île-de-France, 2007, p. 4). It repeated its concern over what was now deemed a "worrying situation", especially in the light of the "considerable burden and risk" the Docks project represented (Chambre régional des comptes d'Île-de-France, 2012, pp. 10-13). However, local executives view debt in a similar way to taxation: as a means of redistribution through significant public investment (Interview 020, former Deputy Mayor).

$<<$ Insert Figure 2 here $>>$

The Docks case-study covers a ten-year period and retraces two major instances where the financialization of commercial properties was negotiated, as we demonstrate in the two sections that follow. While the provision of building-asfinancial-assets underpinned the property company Nexity's initial scheme to acquire and redevelop 18 ha of land, the local authority's reaction led to the development of a partnership framework (section 5). Having thereby secured its land development strategy, Nexity negotiated some key aspects of the wider redevelopment agenda with the municipality, in order to meet market standards reflecting the criteria of financial investors (section 6).

\section{The financialization of property as a catalyst for the redevelopment project}

The early steps of the Docks redevelopment initiative indirectly - but crucially - involved financial investors. The ability of a major property development holding company to acquire a major tract of land (18 ha) was based on the revenues expected from the sale of pre-leased commercial real estate buildings to investors. The developer's initiative triggered negotiations around the approval of building permits, which gradually led to a wider debate on the principles of the municipality's own redevelopment plan. As a result, a partnership framework was agreed between the municipality and the developer. 
The property development holding company's ability to acquire land and thus to secure a substantial pipeline to development rights for the whole 18 ha was underpinned by a sale-and-leaseback scheme with the former landowner, the publicly-listed French multinational, Alstom. The latter initially wanted to outsource its existing real estate under its 2002 Restore Value plan, geared towards reducing the company's debt level and thus regaining shareholders' waning confidence (Les Échos, 23/09/2003), while also bringing its employees together on a single site (Le Parisien, 24/10/2009). In March 2004, Nexity's commercial development department finalized the purchase of the company's 18 ha of land in the eastern part of the current Docks site, now known as 'Dhalenne' (see Figure 2). Under the municipality's zoning rules at the time, development rights were limited to low-density, non-residential development. On this basis, Nexity assessed the potential for developing a substantial portion of office floorspace which would serve as a "gauge" for the full-scale launch of Nexity's Dhalenne plan (Interview 004, property holding, land development, manager). Under the sale-and-leaseback scheme, Nexity would acquire Alstom's premises while providing the firm with two new buildings on a 6 to 9 years lease. Land purchase was conducted through a Special Purpose Vehicle (AMF, 2004), development rights were acquired by Nexity's in-house commercial development department (Nexity Immobilier d'Entreprise), and the two pre-leased buildings were then sold to institutional investors in mid-2007 before their actual completion in 2009 (see Figure 3).

$<<$ Insert Figure 3 here $>>$

Consistent with current techniques that emerged with the arrival of financial investors on the property market, this scheme was thus based on a combination of rental streams and tradable buildings, which allowed Nexity to secure land supply for the next two decades in a promising market location. First, the rental income from Alstom's leases covered $10 \%$ to $20 \%$ of the land acquisition (Interview 004, property holding, land development, manager), thus helping to cover the financial costs of locking capital into land ownership. Second, standardized large office properties pre-leased to a blue chip multinational such as Alstom were used to 
attract risk-averse financial investors and thus to generate profits for Nexity's property development business.

Meanwhile, the municipality had identified the Docks as a key site of intervention only a few months before (Ville de Saint-Ouen, 2004). Nexity's move put the local authority on the back foot, since the developer's interest confirmed the strategic importance of the site. To gain the upper hand, the local authority quickly approved a "study zone" (périmètre d'études) as a way to "generate regulated development in the area [...] [through] a partnership approach bringing together the different stakeholders [...] in which [the City] has a better understanding of everyone's intentions and is able to make them share its own objectives more effectively" (former Deputy Mayor, quoted in Temam, 2009, p. 79, our translation). This allowed the municipality to buy some time: under the national planning rule, a "study zone" gives a local authority the legal right to refuse a building permit, even in cases where existing zoning requirements would be met. The municipality could thus come up with an alternative project not only for Nexity's Dhalenne sector but for the entire 100 ha (Interview 002, cityappointed architect-planner).

Although its sale-and-leaseback scheme with Alstom was key to initiating further redevelopment, Nexity was nevertheless dependent on building permits being granted by the municipality. This turned out to be an opportunity for the local authority, whose elected officials were keen that the developer should contribute to the provision of infrastructure for the wider population. In exchange for permit approval, the deal was that the developer should give away 6 ha of land to develop a large park in the Docks (Interviews 002, city-appointed architectplanner; 004, property holding, land development, manager; 018, former Deputy mayor).

This compromise reflected a delicate balancing act for the Red Belt local authority. On the one hand, its reluctance to develop new office properties resurfaced: concerns were raised both in pre-operational studies and during meetings with Nexity, on matters such as the risk of architectural uniformity (Interview 019, Economic development consultant). On the other hand, the sale- 
and-leaseback scheme provided the municipal authority with a solution to keep the industrial multinational onsite. At this point, the Mayor joined local efforts to retain Alstom (Temam, 2009, p. 54) - the biggest local employer and a major tax contributor - which had occupied the site since 1917 (Service du patrimoine culturel de la Seine-Saint-Denis, 2005), amidst rumors of a partial shutdown or complete closure. For Alstom's management, remaining on the site would mean combining the engineering and $\mathrm{R} \& \mathrm{D}$ operations, but disposing of waning bluecollar activities. Nevertheless, given the local working-class ethos, the presence of an industrial firm was perceived as being in phase with the locality's interests (Interview 018, former Deputy mayor). Besides, the special planning zone (ZAC) had not yet been created, so that, despite its eagerness the local authority lacked the regulatory tools to be able to tax property development. It therefore set out to obtain payment in kind. This bargain was perceived as pivotal for elected officials, who had realized by this time that the fate of the 100 ha plan was wound up with Nexity's own project. By its sheer presence and the development of two brand-new buildings, Nexity was de facto strongly influencing the phasing of the entire redevelopment project (Interview 018, former Deputy mayor; see Figure 2).

The early negotiations quickly led to a wider debate on the principles of the redevelopment plan, over and above the granting of building permits. When it purchased the land, Nexity had assessed the viability of its investment in terms of a pre-determined development threshold of 280,000 sq.m. (Interview 016, DC, former Project director), the surface area deemed profitable in the light of current (and future) market circumstances and existing zoning conditions. The agreement to give away part of its land in exchange for permit approvals depended in turn upon the local authority's willingness to accommodate the 280,000 sq.m. on a plot of land that had lost one-third of its surface area to the municipal park. This would entail a wider revision of the existing zoning plan to allow for mixed-use development and the removal of the statutory density threshold. Given the municipality's own redevelopment agenda (see section 3), the zoning was bound to change, but the conditions of this change were tackled in the context of the negotiations with Nexity. 
This accordingly meant discussing and adjusting Nexity's project, thus shifting the debate to the issue of planning principles, and, as we consider below, potentially challenging the municipality's agenda to the expectations of investors, as conveyed by Nexity's planning and land development department (Villes \& Projets). As a result, a partnership framework was established through a tripartite agreement signed in 2007 and revised in 2012 (Ville de Saint-Ouen et al., 2012), which summarized each party's rights and obligations, though in a manner more morally than legally binding. The agreement strengthened Nexity's landownership position: in addition to validating its sale-and-leaseback scheme by granting the permit approvals for the two buildings pre-leased to Alstom, the partnership allowed the property company to negotiate the project, from the masterplan through to its own financial contribution. Furthermore, the agreement also represented a way to secure outcomes for the initially targeted 280,000 sq.m, such as the quantity, type, and conditions of building rights. This aspect was crucial for the Nexity holding company, whose core business is real estate development.

\section{Negotiating the agenda on behalf of financial investors}

The planning and land development unit Villes \& Projets has been spearheading negotiations with the local authority. This unit is not a profit center but rather a department that seeks to generate development opportunities for the firm's in-house real estate development departments (Interviews 004, 008, and 015, property holding, land development, commercial properties, and real estate and investment management). It therefore calibrates redevelopment plans to support the holding company's development pipeline and transfers development rights to its in-house property development departments (such as its commercial property unit Nexity Immobilier d'Entreprise).

Following the restructuring of property markets, with investors increasingly becoming end buyers (Guironnet \& Halbert, 2014), the commercial property development department Nexity Immobilier d'Entreprise looks to supply buildings that qualify as financial assets: 
"[when asked for what type of lessees they looked for] Ideally, a single tenant for the longest lease possible - with signature clients - in order to turn an investment product into a bond: a 12 years-long lease to IBM, for example" (Interview 008 , property holding, commercial properties, manager).

The result is that the developers have come to share the criteria of investors for new properties (see Halbert et al., 2014b, pp. 259-269 for more details on these). They include inter alia: minimum floor space (10,000 to 20,000 sq.m.), building specifications of so-called 'international standards' (minimum ceiling heights and floor space, connectivity equipment, green labels, etc.), location in relation to public transportation, density of commercial properties within the immediate vicinity, and types of tenants - 'blue chip' tenants being key in attracting potential investors by offering them a secure income-generating asset.

Within Nexity's business organization, Villes \& Projets is therefore at the forefront of negotiations with the local authority on behalf of in-house developers, whose business depends on tailoring assets to a financial clientele. By analyzing these negotiations, we can gauge the city government's ability to steer its urban redevelopment project when confronted with the expectations of property investors (as mediated by the developer).

The negotiations focused first and foremost on urban design. ${ }^{7}$ The local authority championed the sharing of parking lots between end-users of different building types (housing, retail, and office) as part of a political commitment to sustainable mobility through reduced car-use (Interview 005, DC, project manager). Nexity vehemently opposed this principle under the belief that it failed to address market needs. Claiming an intimate understanding of the market, the developer was adamant that some of the parking lots should be excluded from any sharing arrangement to limit the risk of offices remaining vacant (Interview 004, property holding, land development, manager) and thus to ensure investors' interest in the scheme. As a result, instead of all the parking spaces being shared, $50 \%$ are restricted to office users in the Dhalenne sector. This quota was enshrined 
in the revised tripartite convention of 2012, with the explicit objective of accommodating "commercial property market expectations" (Ville de Saint-Ouen et al., 2012, art. 8.2). Interviews with developers (including those active in other parts of the Docks project) and investors corroborated this standard.

A second element of the negotiations concerned the implementation of a mixed-use redevelopment plan, i.e. the official UDP's main rationale as set by the municipality. The masterplan had envisioned a mix of uses at all levels - planning sectors, street block, and individual buildings (Ville de Saint-Ouen et al., 2008). Villes \& Projets negotiated gradual adjustments, resulting in a clear concentration of offices along Rue Paulin Talabot (Interviews 005 and 016, DC, project manager, former project Director; see Figure 2). This reflects an attempt to meet currently accepted investment market standards (Interview 011, developer-appointed architect-planner), i.e. the investment industry's belief that 'liquidity' stems from the geographic concentration of similar buildings. As one investment manager of a pan-European fund put it, the investment decision for a given building takes into account the total surface area of other offices in the immediate vicinity, as this is believed to influence both resale and rental liquidity (Interview 013). Similarly, interviewees reported that the investment industry was unfavorable to built-in street-level retail units in office properties (Interviews 016, DC, former Project director; 017, Developer, project manager; 019, Economic development consultant), which was therefore not implemented in Nexity's office developments. This runs counter to the municipality's aim of developing vibrant commercial streets, especially in this particular area which links the Docks area to an existing metro station.

These two examples illustrate how the urban design of the original redevelopment project has been altered to meet the expectations of potential investors. The retrofitting of Alstom's 1921 M.A.N. industrial hall offers another illustration, this time at the juncture between issues of urban design and economic development. As a tribute to the site's industrial heritage, the local authority had revised its zoning rules to allow for the restoration of one of the three former halls (Ville de Saint-Ouen, 2008, chap. 5), a plan mentioned in the tripartite agreement with Nexity (Ville de Saint-Ouen et al., 2012, art. 2). The latter was nonetheless 
reluctant, since the hall supposedly lacked viability in terms of potential use of space (Interviews 008, property holding, commercial properties, project manager; 011, developer-appointed architect-planner). This "atypical space", which would most probably be occupied by 'non-blue chip' lessees, appeared to fall short of institutional investors' standards. This was further confirmed when a medium-sized design company announced its readiness to transfer its existing headquarters in southern Saint-Ouen to occupy part of the M.A.N. hall in 2011. This came as a timely vindication of the local authority's claim to be part of the northern Grand Paris creative industries cluster, which was in preliminary discussions with the State. Nexity finally agreed to refurbish the building on condition that the occupant would buy the premises. The developer was adamant about not locking up capital in the building through ownership, while interviews with investors confirmed their reluctance to engage with these types of properties and lessees. All in all, this has left the municipality with a zoning regulation to protect the built environment, but limited solutions to ensure alternative uses. At the time of the interviews, in spite of the local design company's attempt to get Saint-Ouen to compete with the nearby Saint-Denis Red Belt municipality to host his project for a "Cité du design" (Le Parisien, 14/03/2012), it remained unclear how the hall could be retained unless the municipality directly acquired the building (which raises the question of its financial ability to do so). ${ }^{8}$ This highlights the limitations of a project based on financializing property markets, which prove reluctant to support non-standard redevelopments.

The M.A.N. case epitomizes the conundrum faced by local authorities when it comes to steering economic development through a UDP. City governments have limited influence on investor choices once properties are effectively developed and sold, a reality that in this case undermines the municipality's attempt to provide jobs for its residents in order to prevent their ongoing displacement because of rising land prices. With no leverage over landlords' rental strategies, municipal efforts to limit the widening spatial mismatch between newly created jobs and the qualifications of local residents are restricted to attempts to influence office tenants. Some have been persuaded by Saint-Ouen, as in other Red Belt 
municipalities, to ratify a non-binding ethical charter giving preference to the recruitment of local workers, especially for low-skilled jobs (Interview 010, Municipal administration, economic development).

\section{Conclusion}

Responding to the call for research into financialization from the perspective of city governments, the study of the 100 ha Docks project in a pericentral location of the Paris city-region casts light on the ability of a local authority to implement its urban redevelopment policy when financial investors are "knocking at the door".

In empirical terms, the research demonstrates that this ability varies according to the issues at stake. In terms of urban design, the municipality was able to pursue some of its objectives through the use of existing planning tools (e.g. delivery of a 12 ha park). These tools made it possible both to regulate the intervention by private developers and to levy tax on part of the development value - in kind or in cash. This supported public investment in infrastructure, public space, and services. However, the initial project was challenged by real estate developers such as the Nexity property company, which forced the local authority to consider "market expectations", i.e. the requirements of the end buyers of business properties financial investors. Initial proposals for sustainable mobility (shared parking lots) and mixed land-use (between and within buildings) were thus watered down to accommodate the industry's investment expectations.

With regard to economic development, the municipality's support for a diversity of economic activities, which is part of a wider objective of socio-spatial cohesion, was undermined. Firstly, the fact that it is the property investors that select their tenants - applying their own financial standards - deprives the local authority of influence. This demonstrates the limits of planning as a lever for steering economic development. Secondly, there is the local authority's limited self-perceived legitimacy to invest in and, to some extent, to influence the provision of business property. In Saint-Ouen, by contrast with housing, where the municipality financially supports a high proportion of social units, and adopts 
stringent regulations on the provision of market housing (such as caps on prices), it is only in very exceptional cases that the city government challenges property investors' expectations. The M.A.N. hall is a notable exception in that respect, where the convergence of several major objectives (supporting local industrial identity and heritage while promoting a digital industry cluster) probably explains why negotiations have occurred. Consequently, although substantial social housing developments and policies that attempt, at least momentarily, to check the rise in housing market prices, may help to limit the displacement of lower-income groups from Saint-Ouen, the redevelopment initiative will most likely fail to reduce the widening spatial mismatch between the employment profiles of newly established firms and those of the existing local population. The aim of pursuing economic diversity through urban redevelopment is thus undermined by the difficulty of making space for economic activities other than those favored by financial investors. Furthermore, as new developments transform the area, it is likely that existing activities such as light industry and logistics will be pushed further out, as has happened in other pericentral localities in the metropolis.

At a theoretical level, the research demonstrates that when real estate is increasingly treated as an asset in financial portfolios, the outcomes of UDPs are best understood as the results of power relations between a city government with its own multifold objectives, and the expectations of financial investors about what cities should be. Be it the location of buildings, public amenities and infrastructure within a city-region or within an UDP, or the permitted uses of buildings and preferences about who their users should be, the objectives of city governments may be challenged by so-called market standards that reflect the translation of ever-changing financial categories (risk, return, and liquidity) into elements of the urban fabric, and vice-versa. This translation is not the straightforward operation of a universal principle of land value maximization applicable to all economic agents, as is sometimes argued in the academic literature. It is rather the outcome of a social process pursued by financial intermediaries with the combined objectives of improving returns and limiting risks. These objectives are circulated by - and to other actors such as developers, whose business strategy is now to provide these investors with "quasi-financial assets". 
This perspective on financialization brings us back to Harvey's argument about the trading of land "according to the rent it yields", whereby "for the buyer, the rent $(. .$.$) is in principle no different from similar investments in government debt,$ stocks and shares of enterprises, consumer debt and so on" (2006 [1982], p. 347). For this is precisely what is remarkable about the ongoing financialization of real estate, which rests on the ability of financial investors to compare returns in property on a global scale and with other financial assets. Yet, as discussed in this paper, it is crucial to highlight the expectations of financial investors, which are underpinned by a whole set of strategies, practices, and techniques derived from modern market finance. By factoring these into the analysis of urban redevelopment projects, we can unveil the very power relationships that unfold through their dissemination.

This has important policy implications, since power relationships in the definition and implementation of urban redevelopment projects may increasingly be tilted in favor of financial investors, for two reasons. First, the financialization of "structures of building [and infrastructure] provision" (Ball, 1986) is likely to be reinforced by national and supra-national policies (in the form of public-private financing and mutual investment funds). In 'emerging' countries, financial markets are called on to respond to the surging demand for infrastructure and housing in fast-growing cities (see Rouanet and Halbert $C$, this special issue). In old industrial countries, such financial circuits are believed to bring the improvements in the material infrastructure needed to stimulate slack economic growth while offering financial opportunities to support the needs of ageing populations. The second reason lies in the growing constraints on city governments themselves. Because of the rising concern over public finances and a level of public debt that peaked following the effects of the GFC, city governments may see a severe curtailment in their investment capacity, and hence in their ability to bear the cost of urban redevelopment while pursuing their own objectives. National austerity packages that prioritize public debt reduction will most probably further limit financial transfers from the central state to city governments. Slow economic growth may impede the ability of local authorities to use taxation to redistribute wealth. City governments that wish to redevelop parts of their territories may thus increasingly 
be forced to rely on property markets, and thus to accommodate the expectations of those financial intermediaries which channel investment into the built environment. In the face of these very likely developments, it is urgent that scholars in urban studies attempt a more systematic analysis of the financialization of structures of building and infrastructure provision. 


\section{References}

Aalbers, M. (2012). Subprime cities the political economy of mortgage markets. Chichester, West Sussex; Malden, MA: Wiley-Blackwell.

Albecker, M.-F. (2009). Globalisation et politiques urbaines locales dans la première couronne de la banlieue parisienne: une spécificité communiste? Paper presented at the Symposium Les territoires du communisme. Élus locaux, politiques publiques et sociabilités militantes. Paris: Université Paris 1 Panthéon-Sorbonne.

AMF. (2004). Nexity : Document de base. Paris: Autorité des Marchés Financiers.

Attuyer, K., Guironnet, A., \& Halbert, L. (2012a). La ville à 7\%. Stratégies d'investissement, politiques publiques et droit de cité. Urbanisme, (384), pp. $72-74$.

Attuyer, K., Guironnet, A., \& Halbert, L. (2012b). "Turning pumpkins into carriages": Sustainable Urban Developement and the Financialization of "Green" Commercial Real Estate in France. Articulo - Journal of Urban Research, 9, pp. 1-16. Retrieved from http://articulo.revues.org/2155

Ball, M. (1986). The built environment and the urban question. Environment and Planning D: Society and Space, 4(4), pp. 447 - 464.

Bellanger, E. (2013). Le « communisme municipal» ou le réformisme officieux en banlieue rouge, in: E. Bellanger \& J. Mischi (Eds.), Les territoires $d u$ communisme. Elus locaux, politique publique et sociabilité militante (Des années 1920 à nos jours), pp. 27-52. Recherches. Paris: Armand Collin.

Caillosse, J., Le Galès, P., \& Loncle-Moriceau, P. (1997). Les sociétés d'économie mixte locales : outils de quelle action publique?, in: Le gouvernement des villes. Territoire et pouvoir. Les urbanités. Paris: Descartes \& Cie, pp. 23-96.

Chambre régionale des comptes d'Île-de-France. (2007). Rapport d'observations définitives. Commune de Saint-Ouen (93). Exercices 2000 à 2003. Noisiel: Chambre régionale des comptes d'Île-de-France.

Chambre régionale des comptes d'Île-de-France. (2012). Rapport d'observations définitives. Commune de Saint-Ouen (93). Exercices 2004 et suivants. Noisiel: Chambre régionale des comptes d'Île-de-France.

Charnock, G., Purcell, T. F., \& Ribera-Fumaz, R. (2014). City of Rents: The limits to the Barcelona model of urban competitiveness. International Journal of Urban and Regional Research, 38(1), pp. 198-217.

Christophers, B. (2010). On voodoo economics: theorising relations of property, value and contemporary capitalism. Transactions of the Institute of British Geographers, 35(1), pp. 94-108. 
Coakley, J. (1994). The integration of property and financial markets. Environment and Planning A, 26(5), pp. 697-713.

Crosby, N., \& Henneberry, J. (2016). Financialisation, the valuation of investment property and the urban built environment in the UK. Urban Studies, 53(7), pp. $1424-1441$.

David, L. (2013). La production urbaine de Mexico: entre financiarisation et construction territoriale. Une analyse de l'insertion du réseau financier transnational dans les marchés d'immobilier d'entreprise. $\mathrm{PhD}$ thesis, Universite Paris-Est.

David, L., \& Halbert, L. (2014). Finance Capital, Actor-Network Theory and the Struggle Over Calculative Agencies in the Business Property Markets of Mexico City Metropolitan Region. Regional Studies, 48(3), pp. 516-529.

Erturk, I., Froud, J., Johal, S., Leaver, A., \& Williams, K. (2008). General Introduction. Financialization, coupon pool and conjuncture, in: Financialization at Work. Key texts and commentary. London; New York: Routledge, pp. 1-43..

Espeland, W. N., \& Stevens, M. L. (1998). Commensuration as a Social Process. Annual Review of Sociology, 24(1), pp. 313-343.

Fainstein, S. S. (2001). The city builders: property development in New York and London, 1980-2000. Lawrence, KS: University Press of Kansas.

Fourcaut, A. (1995). Banlieue rouge (J.-F. Sirinelli, Ed.). Dictionnaire historique de la vie politique française au XXe siècle. Paris: Presses Universitaires de France, pp. 77-82.

Fourny, M.-C. (1986). Politiques locales et désindustrialisation en proche banlieue parisienne. Hérodote, (43), pp. 123-139.

Le Galès, P. (2012). Constructions of Neoliberal Reason - By Jamie Peck. International Journal of Urban and Regional Research, 36(4), pp. 868-871.

Gotham, K. F. (2006). The Secondary Circuit of Capital Reconsidered: Globalization and the U.S. Real Estate Sector. American Journal of Sociology, 112(1), pp. 231-75.

Guironnet, A., \& Halbert, L. 2014. The financialization of Urban Development Projects: Concepts, processes, and implications. Document de travail du LATTS - Working Paper (4). https://hal-enpc.archives-ouvertes.fr/hal-01097192

Guy, S., Henneberry, J., \& Rowley, S. (2002). Development Cultures and Urban Regeneration. Urban Studies, 39(7), pp. 1181-1196. 
Haila, A. (1988). Land as a Financial Asset: The Theory of Urban Rent as a Mirror of Economic Transformation*. Antipode, 20(2), pp. 79-101.

Halbert, L. (2007). Grands projets urbains: lieux de convergence des stratégies publiques et privées. Cahiers de L'I.A.U.R.I.F., (146), pp. 101-107.

Halbert, L. (2008). Examining the Mega-City-Region Hypothesis: Evidence from the Paris City-Region/Bassin parisien. Regional Studies, 42(8), pp. 1147-1160.

Halbert, L. (2013). Les acteurs des marchés financiers font-ils la ville? Vers un agenda de recherche. EspaceTemps.net. Retrieved from http://www.espacestemps.net/articles/les-acteurs-des-marches-financiers-fontils-la-ville-vers-un-agenda-de-recherche/

Halbert, L., Henneberry, J., \& Mouzakis, F. (2014a). Finance, Business Property and Urban and Regional Development. Regional Studies, 48(3), pp. 421-424.

Halbert, L., Attuyer, K., Boisnier, C., Bouché, P., Decoster, E., Guironnet, A., et al. (2014b). Résistances. Capital financier, immobilier d'entreprise et métropole durable. Latts, Université Paris-Est.

Harvey, D. (1978). The urban process under capitalism: a framework for analysis. International Journal of Urban and Regional Research, 2(1-4), pp. 101-131.

Harvey, D. (1989). From Managerialism to Entrepreneurialism: The Transformation in Urban Governance in Late Capitalism. Geografiska Annaler, 71(1), pp. 3-17.

Harvey, D. [1982] (2006). The Limits to Capital. London; New York: Verso.

Healey, P. (1994). Urban policy and property development: the institutional relations of real-estate development in an old industrial region. Environment and Planning A, 26(2), pp. 177 - 198.

Healey, P., Davoudi, S., O’Toole, M., Tavsanoglu, S., \& Usher, D. (Eds.). (1992). Rebuilding the city: property-led urban regeneration. London: E \& FN Spon.

Henneberry, J., \& Mouzakis, F. (2014). Familiarity and the Determination of Yields for Regional Office Property Investments in the UK. Regional Studies, 48(3), pp. 530-546.

Henneberry, J., \& Roberts, C. (2008). Calculated Inequality? Portfolio Benchmarking and Regional Office Property Investment in the UK. Urban Studies, 45(5-6), pp. 1217-1241.

Janvier, Y. (1996). Nouveaux enjeux de société, in: L'aménagement en questions. Paris-La Défense, France: ADEF, pp. 13-84.. 
Kaika, M., \& Ruggiero, L. (2016). Land Financialization as a "lived" process: The transformation of Milan's Bicocca by Pirelli. European Urban and Regional Studies 23(1), pp. 3-22.

Knorr-Cetina, K., \& Preda, A. (2005). The sociology of financial markets. Oxford; New York: Oxford University Press.

Leyshon, A., \& Thrift, N. (2007). The Capitalization of Almost Everything: The Future of Finance and Capitalism. Theory, Culture \& Society, 24(7-8), pp. 97115.

Lizieri, C. (2009). Towers of capital: office markets \& international financial services. Chichester, U.K.; Ames, Iowa: Wiley-Blackwell Pub.

Martelli, R. (2014). L'archipel urbain du PCF. Métropolitiques. http://www.metropolitiques.eu/L-archipel-urbain-du-PCF.html

Marty, G. (2004). L'invention de l'asset management. Réflexions Immobilières, (38), pp. 20-25.

Menez, F. (2008). Le partenariat public privé en aménagement urbain : évolution et métamorphose de la maîtrise d'ouvrage urbaine des années 1960 à nos jours - Analyse à partir du cas lyonnais. $\mathrm{PhD}$ thesis, Universite Lyon 2.

Moreno, L. (2014). The urban process under financialised capitalism. City, 18(3), pp. 244-268.

Moulaert, F., Rodríguez, A., \& Swyngedouw, E. (Eds.). (2003). The globalized city: economic restructuring and social polarization in European cities. Oxford: Oxford University Press.

Nappi-Choulet, I. (2006). The role and behaviour of commercial property investors and developers in French urban regeneration: The experience of the Paris region. Urban Studies, 43(9), pp. 1511-1535.

Nappi-Choulet, I. (2002). L'externalisation des patrimoines immobiliers, un phénomène structurel? Réflexions Immobilières, (33), pp. 41-49.

Nappi-Choulet, I. (2009). Les mutations de l'immobilier: De la finance au développement durable. Paris: Editions Autrement.

Orueta, F. D., \& Fainstein, S. S. (2008). The New Mega-Projects: Genesis and Impacts. International Journal of Urban and Regional Research, 32(4), pp. 759-767.

Pouvreau, B. (2009). Quand communisme municipal rimait avec laboratoire urbain (1944-1986). Paper presented at the Symposium Les territoires $d u$ communisme. Élus locaux, politiques publiques et sociabilités militantes. Paris: Université Paris 1 Panthéon-Sorbonne. 
Préfecture de la Région d'Île-de-France, \& Direction régionale de l'équipement. (1994). Ile-de-France. Schéma Directeur.

Pryke, M. (1994). Looking back on the space of a boom: (re)developing spatial matrices in the City of London. Environment and Planning A, 26(2), pp. 235 264.

Raco, M., \& Henderson, S. (2009). Flagship Regeneration in a Global City: The Re-making of Paddington Basin. Urban Policy and Research, 27(3), pp. 301314.

Halbert, L., \& Rouanet, H. (2014). Filtering Risk Away: Global Finance Capital, Transcalar Territorial Networks and the (Un)Making of City-Regions: An Analysis of Business Property Development in Bangalore, India. Regional Studies, 48(3), pp. 471-484.

Rutland, T. (2010). The Financialization of Urban Redevelopment. Geography Compass, 4(8), pp. 1167-1178.

Sequano Aménagement. (2014). Écoquartier des Docks. Séquano Aménagement Autrement la ville. http://www.sequano.fr/portfolio/ecoquartier-des-docks/

Searle, L. G. (2014). Conflict and Commensuration: Contested Market Making in India's Private Real Estate Development Sector. International Journal of Urban and Regional Research, 38(1), pp. 60-78.

Service du patrimoine culturel de la Seine-Saint-Denis. (2005). Les docks de SaintOuen. Un état des lieux patrimonial. Conseil général de Seine-Saint-Denis.

Stevenson, S., Akimov, A., Hutson, E., \& Krystalogianni, A. (2014). Concordance in Global Office Market Cycles. Regional Studies, 48(3), pp. 456-470.

Subra, P. (2004). Île-de-France : la fin de la banlieue rouge. Hérodote, 113(2), p. $14-27$.

Swyngedouw, E. (2005). A New Urbanity? The ambiguous politics of large-scale urban development projects in European cities, in: W. Salet \& S. Majoor (Eds.), Amsterdam Zuidas. European Space. Rotterdam: 010 Publishers, pp. 61-79.

Taşan-Kok, T. (2010). Entrepreneurial Governance: Challenges of Large-Scale Property-Led Urban Regeneration Projects. Tijdschrift voor economische en sociale geografie, 101(2), pp. 126-149.

Taşan-Kok, T. (2012). Introduction: Contradiction of Neoliberal Urban Planning, in: T. Taşan-Kok \& G. Baeten (Eds.), Contradictions of Neoliberal Planning. Cities, Policies, and Politics. London: Springer, pp. 1-20. 
Temam, S. (2009). Les Docks de Saint-Ouen. La négociation comme instrument de la coopération public-privé. MA thesis, Institut Français d'Urbanisme, Universite Paris 8

Theurillat, T., \& Crevoisier, O. (2014). Sustainability and the Anchoring of Capital: Negotiations Surrounding Two Major Urban Projects in Switzerland. Regional Studies, 48(3), pp. 501-515.

Torrance, M. I. (2008). Forging Glocal Governance? Urban Infrastructures as Networked Financial Products. International Journal of Urban and Regional Research, 32(1), pp. 1-21.

Turok, I. (1992). Property-led urban regeneration: panacea or placebo? Environment and Planning A, 24(3), pp. 361-379.

Ville de Saint-Ouen. (2004). Plan d'Aménagement et de Développement Durable (PADD).

Ville de Saint-Ouen. (2008). Plan Local d'Urbanisme.

Ville de Saint-Ouen, \& Sequano Aménagement. (2010). Dossier de réalisation ZAC des Docks ville de Saint-Ouen.

Ville de Saint-Ouen, Sequano Aménagement, \& Nexity. (2012). Convention tripartite entre la ville de Saint-Ouen - Séquano Aménagement et NEXIMMO 12. Article L311-5 du Code de l'Urbanisme.

Ville de Saint-Ouen, Sequano Aménagement, Rafatdjou, M., Reichen, B., Tarraso, O., Saudecerre, H., et al. (2008). Schéma Directeur d'Aménagement des Docks de Saint-Ouen.

Ville de Saint-Ouen, Sequano Aménagement, Resources, \& Adage environnement. (2009). Complément à l'étude d'impact.

Weber, R. (2010). Selling City Futures: The Financialization of Urban Redevelopment Policy. Economic Geography, 86(3), pp. 251-274.

Wolf-Powers, L. (2005). Up-Zoning New York City's Mixed Use Neighborhoods : Property-Led Economic Development and the Anatomy of a Planning Dilemma. Journal of Planning Education and Research, 24(4), pp. 379-393. 


\section{List of figures}

Figure 1: Location of Saint-Ouen municipality in the Paris city-region

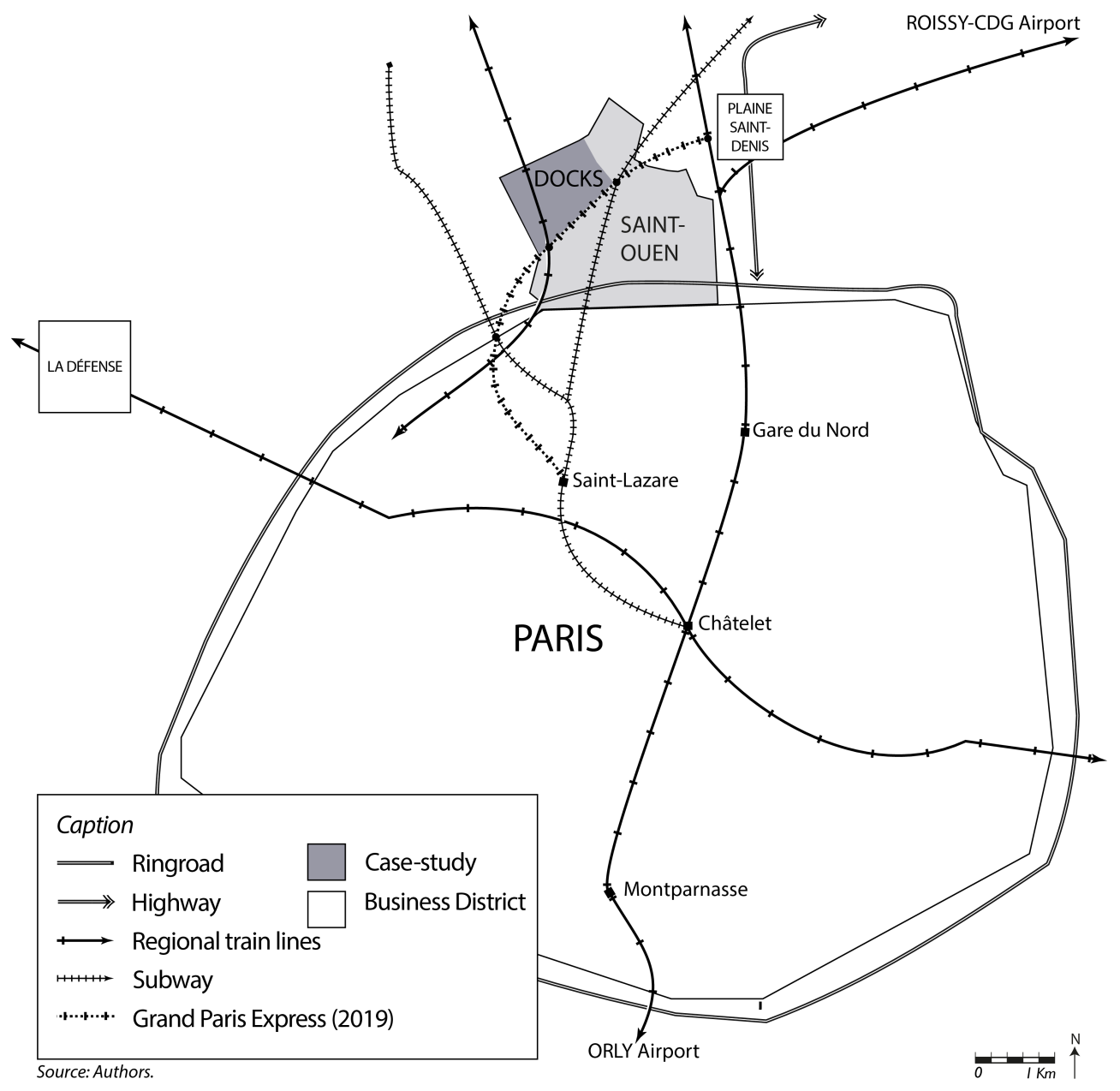


Figure 2: Docks Urban Development Project - location, masterplan, and projected construction

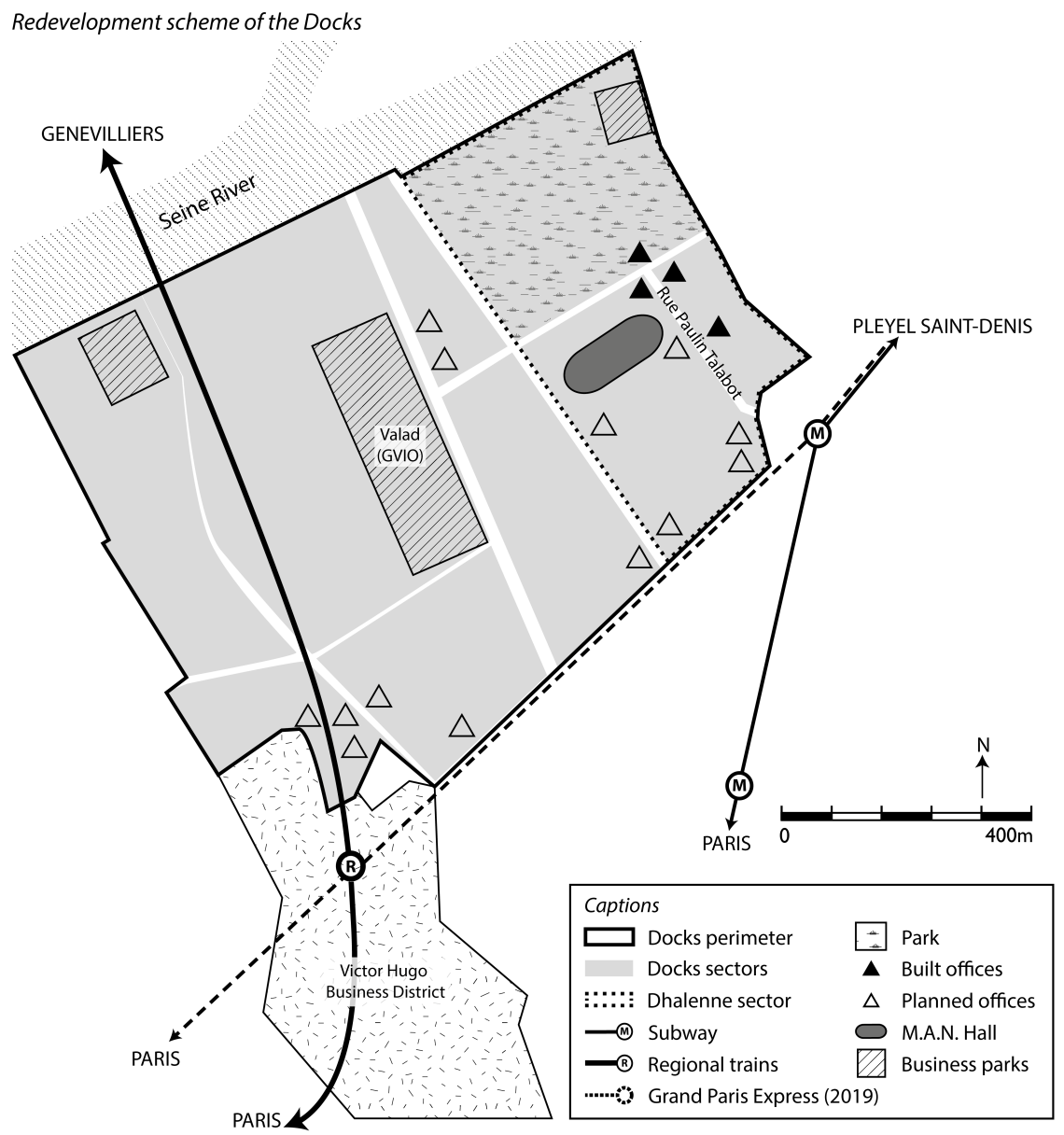

Size of projected development in the ZAC des Docks as of 2010 (in SHON sq.m.)

\begin{tabular}{lcccc} 
& \multicolumn{2}{c}{ ZAC des Docks } & \multicolumn{2}{c}{ Dhalenne sector } \\
type of property & sq. $m$. & $\%$ & sq. $m$. & $\%$ \\
\hline housing & 387,000 & 47 & 162,511 & 48 \\
office & 308,000 & 37 & $131,685^{*}$ & 39 \\
business & 14,800 & 1 & 14,800 & 5 \\
retail & 60,000 & 7 & 21,470 & 6 \\
equipment & 69,000 & 8 & 7,384 & 2 \\
\hline TOTAL & $\mathbf{8 2 4 , 3 1 0}$ & $\mathbf{1 0 0}$ & $\mathbf{3 3 7 , 8 5 0}$ & $\mathbf{1 0 0}$
\end{tabular}

* including office buildings 'Sigma' and 'Kappa' developed prior to the ZAC Source: Authors, based on Ville de Saint-Ouen et al. (2008) and (2009). 
Figure 3: Sale-and-leaseback scheme between Alstom and Nexity

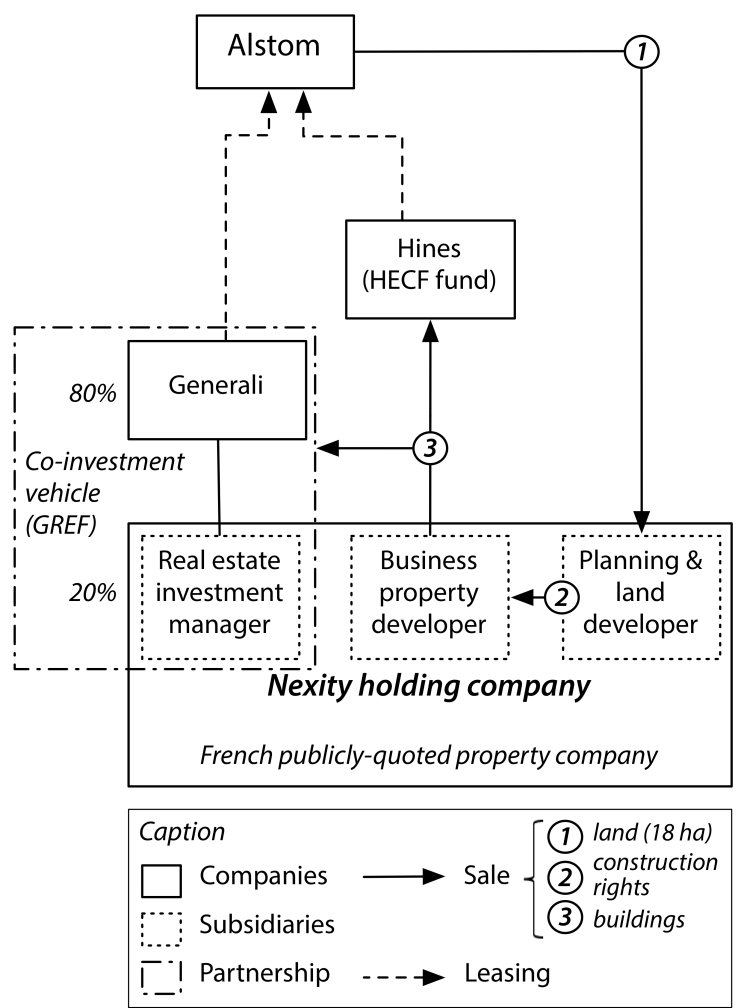

Source: Authors, based on interviews.

\footnotetext{
${ }^{1}$ When property investors' asset management techniques are factored in, as the present paper suggests, it might appear that small KBE firms were evicted not so much on the basis of their inability to pay expensive rents, but because risk-averse institutional investors are reluctant to rent out their premises to start-ups with shorter financial track records than to blue chip tenants (Halbert et al., 2014b).

${ }^{2}$ Thus, with Christophers (2010, p. 98), we acknowledge that the discussion of this specific argument may not compromise Harvey's larger theoretical framework, which is beyond the scope of this article, nor related concepts such as capital switching (Harvey, 1978).

${ }^{3}$ With the varying scale of contributions by other intermediaries such as developers and property consultants that make up "transcalar territorial networks" (Rouanet \& Halbert, 2014; Guironnet \& Halbert, 2014)

${ }^{4}$ In 1977, the French Communist Party assumed the executive leadership of 147 municipalities, i.e. $30 \%$ of the Paris regional population (as against $12 \%$ in 2008 and $10 \%$ in 2014) (Martelli 2014), leading Subra (2004) to declare "the end of the Red Belt".
} 
${ }^{5}$ The use of "opportunistic" is not pejorative; this is a term used by the investment industry to qualify investment strategies and assets that aim for higher returns through higher risk (as opposed to risk-averse "core" profiles).

${ }^{6}$ In France, DCs are usually either under the authority of central government (Établissements Publics d'Aménagement) or of local government (e.g. Société d'Économie Mixte). In the latter case, akin to an arm's length relationship, local authorities have to hold a majority of shares. The major shareholder in Sequano is the Seine-Saint-Denis district (département) (62\%), in which Saint-Ouen is located. As a result, given her elected position at the district assembly, SaintOuen's mayor sits on Sequano's board.

${ }^{7}$ Urban design is understood in this paper as the overall organization of the built environment, such as land-use, public space, etc.

${ }^{8}$ Since then, the local design company and the developer have signed a leasing agreement (Le Parisien 18/06/2013) and the refurbishment has been officially launched (Ibid, 16/08/2014), although both the financing of the Cité du design and the use of the remaining space within the M.A.N. hall remain unclear. 